\title{
Physiological quality of sweet sorghum [Sorghum bicolor (L.) Moench.] seeds in response to planting density in semi-arid region
}

\author{
Tatiana Maria da Silva ${ }^{1}$, Maria de Fátima de Queiroz Lopes ${ }^{2}$, Alexandre Bosco de Oliveira ${ }^{1 *}$, André \\ Luis da Silva Parente Nogueira ${ }^{1}$, Italo Emerson Trindade Viana ${ }^{1}$, Bruno França da Trindade Lessa ${ }^{3}$ \\ ${ }^{1}$ Federal University of Ceará, Ceará, Brazil \\ ${ }^{2}$ Federal University of Paraíba, Paraíba, Brazil \\ ${ }^{3}$ Federal University of Vale do São Francisco, Pernambuco, Brazil
}

*Corresponding author: aleufc@gmail.com

\begin{abstract}
Sweet sorghum is a bioenergy crop that produces high amount of ethanol per hectare even under semi-arid conditions, serving as an alternative to sugarcane inter-season in Brazil. The aim of this study was to evaluate the influence of planting density on the physiological quality of sweet sorghum seeds. Two sweet sorghum cultivars (BRS 506 and SF-15) were submitted to a spacing of 50, 60,70 and $80 \mathrm{~cm}$ between rows, and 8,12 and $16 \mathrm{~cm}$ between plants. The experimental design was of randomised blocks with four replications in a $2 \times 4 \times 3$ factorial scheme, comprising two cultivars, four row spacings and three spacings between plants. The following were evaluated from the collected panicles: seed quantity, 100 seed weight, water content, germination, first germination count and speed of germination, accelerated ageing, and seedling vigour. It was found that both the cultivar and the arrangement of plants in the field affect the physiological quality of sweet sorghum seeds. The BRS 506 cultivar is recommended for seed production under semi-arid conditions, at a spacing of $16 \mathrm{~cm}$ between plants and $80 \mathrm{~cm}$ between rows, and a density of 78,125 plants per hectare.
\end{abstract}

Keywords: Sorghum bicolor (L.) Moench. Seed production. Spacing.

\section{Introduction}

In view of the global concern with obtaining a renewable source of fuel through clean processes, that would reduce dependence on oil, the cultivation of sweet sorghum (Sorghum bicolor (L.) Moench) is gaining worldwide importance for its potential in the production of ethanol. With biofuels, there is a greater balance between the production and consumption of $\mathrm{CO}_{2}$ in nature, through a reduction in air pollutants produced by cars. Biofuels are therefore one of the main alternatives in reducing the consumption of nonrenewable sources (Cunha and Severo-Filho, 2010).

Sweet sorghum has several advantages as an alternative in the production of ethanol. Noteworthy among these are the short production cycle, on average 90 to130 days, and the high sugar content; the crop is undemanding as to soil fertility, resistant to water stress, and can be used in the sugarcane off-season, a period when the industries are generally non-productive. Furthermore, the residue from sorghum processing can be used as a second-generation energy source and for animal feed (Souza et al., 2005; Fontes et al., 2011; Queiroz et al., 2013).

Sweet sorghum (Sorghum bicolor (L.) Moench) is a promising crop for the semi-arid region due to its resistance to drought and ability to withstand adverse factors, and may therefore be a source of opportunity for the local population by the application of micro-distilleries, which would favour its cultivation in family farming and help to keep people in the field, and increase their source of income by the production of ethanol or other products such as brandy (Ribeiro Filho et al., 2008).

In the production of ethanol, studies into the productivity of sweet sorghum aim to ensure greater efficiency in the use of soil, nutrients and radiation, from a reduction in crop spacing. Fischer-Filho et al. (2014), working with three hybrids of sweet sorghum (Advanta 81981, Monsanto 80007 XBSW and Monsanto 80147 XBSW) at spacings of 45 and $90 \mathrm{~cm}$, observed that at the smaller spacing, with the same number of plants per metre, the height and diameter of the plants were altered, with plants grown at the larger spacing reaching both greater height and a larger diameter.

Fernandes et al. (2014), using the BRS 506 variety and testing five inter-row spacings: four single rows at 50, 60, 70 and $80 \mathrm{~cm}$, and one double row, $100 \times 50 \times 50 \mathrm{~cm}$, in both the harvest season and the off-season, found a significant difference between spacings for the off-season; the authors found that plant height decreased linearly with increases in the spacing between single rows, showing that an increase of $30 \mathrm{~cm}$ in row spacing resulted in plants which were $11.4 \mathrm{~cm}$ smaller.

Another relevant factor in relation to productivity is seed vigour, which is one of the main attributes of physiological quality to be considered in planting a crop, when it is necessary to have knowledge of the physiological quality of the seeds. The use of high vigour seeds is justified in all crops to ensure suitable plant populations over a wide range of environmental field conditions, which would then offer 
ideal agronomic characteristics for, in this case, the production of ethanol. However, information on the effects of plant arrangement on the physiological quality of produced seed is still scarce for this crop (Martins et al., 2014).

In view of the potential of the species for the semi-arid region, and the lack of studies that contribute to the good performance of the crop in the region, the aim of the present study was to evaluate the physiological quality of seeds of two cultivars of sweet sorghum under different planting densities.

\section{Results and Discussion}

\section{General comparison between the cultivars}

The cultivars displayed significant differences $(\mathrm{p}<0.05)$ by non-parametric Kruscal-Wallis test for all the characteristics under study (Table 1). The BRS 506 cultivar was statistically superior for all studied parameters when compared to the SF15 cultivar.

This result can be attributed to the fact of the BRS 506 cultivar having a cycle of 110 days, reaching the point of physiological maturity and making better use of the available resources to complete its final stage. Whereas the SF-15 cultivar had a cycle of 130 days, with the seed thereby remaining attached longer to the mother plant in the field and being subjected to high temperatures, which may possibly have caused a fall in physiological quality (Table 6). According to Evangelista et al. (2015), environmental variations such as relative humidity, temperature and even the action of pathogens, become important causes of loss of physiological potential in seeds between physiological maturity and the time the seed is harvested.

\section{Production of panicles and seeds}

A difference was found in panicle weight for cultivar and plant spacing (Table 1). The BRS 506 cultivar had a greater weight $(59.27 \mathrm{~g})$ compared to the SF-15 cultivar $(50.00 \mathrm{~g})$. However, Pinto et al. (2011), working with the EA 955 cultivar, found a value of $55.28 \mathrm{~g}$ for the characteristic in question, a lower result compared to that obtained with BRS 506. The plant spacing of $16 \mathrm{~cm}$ gave better performance in relation to the other spacings, with a result of $60.62 \mathrm{~g}$. Panicle weight is important, as it is connected to yield, being a criterion for the choice of material to be used for seed production.

There were differences between cultivars in relation to the variable 100 seed weight. The BRS 506 cultivar proved to be statistically superior, with $2.04 \mathrm{~g}$, compared to SF-15 with $1.34 \mathrm{~g}$ (Table 1). According to Carvalho and Nakagawa (2012), this aspect is crucial in the study of seeds, because seeds of greater size and density generally have embryos with high amounts of reserves, and which are healthy and wellformed, giving rise to plants of greater vigour.

There was no significant difference for inter-row spacing $(p \leq 0.05)$ in any of the characteristics being evaluated, showing that these characteristics were not influenced by the spacings used between rows to obtain seeds in the field (Table 1). On the other hand, for the spacing between plants, there was a significant difference $(p \leq 0.05)$ for the characteristic panicle weight, where $16 \mathrm{~cm}$ gave the best result, with an average of $60.62 \mathrm{~g}$, being superior to the other plant spacings for this characteristic. Such a result can be attributed to the greater amount of light captured by the plant being used to facilitate the process of photosynthesis and grain filling. Alvarez et al., (2006) working with maize, noted the opposite, with an increase in density from 55,000 seeds $\mathrm{h}^{-}$ ${ }^{1}$ to 78,125 seeds $h^{-1}$, i.e. a smaller spacing between plants resulted in an increase in grain production, irrespective of the spacing adopted.

\section{Seed physiology quality and seedling establishment}

It can be seen in Table 1, that germination of BRS $506(91 \%)$ seeds were greater than SF-15 cultivar $(80 \%)$. This result can be attributed to interference from intrinsic or environmental factors that possibly affected seed germination. An important aspect of germination in cultivars is that seed quality is only one of the factors for ensuring good productivity, and that in addition, there are other factors that may be directly involved, such as environmental factors, among them water availability, temperature, luminosity and soil fertility. Ullmann et al. (2015), working in the Cerrado region, also found high values for germination percentage when analysing the BRS 506 cultivar, achieving averages of $94 \%$.

In Table 1, it can also be seen that the BRS 506 cultivar presented statistically superior results for shoot length, at $12.09 \mathrm{~cm}$, compared to SF-15 at $10.73 \mathrm{~cm}$. This result can be attributed to seed vigour, where higher values for the average length of normal seedlings from seed samples are evaluated as more vigorous (Toledo et al., 2007).

In relation to the values for dry matter in both the roots and shoots, the BRS 506 cultivar was seen to be statistically superior, with values of $0.0038 \mathrm{~g}$ and $0.0071 \mathrm{~g}$ respectively, while the SF-15 cultivar achieved results of $0.0030 \mathrm{~g}$ for root dry matter and $0.0056 \mathrm{~g}$ for shoot dry matter (Table 1). Carvalho and Nakagawa (2012) state that seed vigour is related to the accumulation of dry matter, and follows this accumulation in the same proportion, displaying maximum vigour when the maximum dry matter weight is reached.

Table 2 shows a summary of the analysis of variance for characteristics that displayed significant values. For the characteristic water content, plant spacing, the interaction of cultivar $\mathrm{x}$ plant spacing, and the triple interaction cultivar $\mathrm{x}$ row spacing $\mathrm{x}$ plant spacing were significant. For the characteristic number of seeds per panicle, only row spacing was significant.

With the germination speed index, significance was seen for cultivar, the interaction cultivar $\mathrm{x}$ row spacing and the triple interaction cultivar $\mathrm{x}$ row spacing $\mathrm{x}$ plant spacing. Whereas with first germination count, significance was seen for cultivar, plant spacing, the interaction row spacing $\mathrm{x}$ plant spacing, and the triple interaction (Table 2).

Root length was significant only for the interaction cultivar $x$ plant spacing. Accelerated ageing had significant values for cultivar, the interaction cultivar $\mathrm{x}$ plant spacing, and the interaction row spacing $\mathrm{x}$ plant spacing.

\section{Seed water content}

In Table 3, there was no difference in water content of the two cultivars at spacings of 50 and $60 \mathrm{~cm}$, but as the interrow spacing increased to $70 \mathrm{~cm}$, there was a significant increase for the SF-15 genotype, followed by a decrease at the next spacing of $80 \mathrm{~cm}$ from $11.6 \%$ to $7.9 \%$.

The BRS 506 cultivar displayed $8.8 \%$ and $9.6 \%$ at a spacing of 50 and $70 \mathrm{~cm}$ between rows respectively, this variation is like those seen by Martins et al. (2014), working with BRS 506 at different spacings, who also found values for seed water content with little variation between treatments, ranging from $15.4 \%$ to $16.5 \%$ at a spacing of 50 and $70 \mathrm{~cm}$ between rows, the same as adopted in this study. 
Table 1. Physical and physiological parameters in seeds of two sweet sorghum cultivars under different planting densities in semiarid region.

\begin{tabular}{|c|c|c|c|c|c|c|}
\hline Treatment & $\mathrm{PW}(\mathrm{g})$ & HSW (g) & $\mathrm{G}(\%)$ & $\mathrm{SL}(\mathrm{cm})$ & RDM (g) & SDM (g) \\
\hline \multicolumn{7}{|l|}{ Cultivar } \\
\hline BRS 506 & $59.27 \mathrm{a}$ & $2.04 \mathrm{a}$ & $91 \mathrm{a}$ & $12.09 \mathrm{a}$ & $0.0038 \mathrm{a}$ & $0.0071 \mathrm{a}$ \\
\hline SF-15 & $50.00 \mathrm{~b}$ & $1.34 \mathrm{~b}$ & $80 \mathrm{~b}$ & $10.73 \mathrm{~b}$ & $0.0030 \mathrm{~b}$ & $0.0056 \mathrm{~b}$ \\
\hline \multicolumn{7}{|c|}{ Spacing between rows } \\
\hline 50 & $49.16 \mathrm{a}$ & $1.69 \mathrm{a}$ & $85 \mathrm{a}$ & $11.32 \mathrm{a}$ & $0.0033 \mathrm{a}$ & $0.0061 \mathrm{a}$ \\
\hline 60 & $51.04 \mathrm{a}$ & $1.71 \mathrm{a}$ & $89 \mathrm{a}$ & $11.75 \mathrm{a}$ & $0.0034 \mathrm{a}$ & $0.0066 \mathrm{a}$ \\
\hline 70 & $57.29 \mathrm{a}$ & $1.69 \mathrm{a}$ & $85 \mathrm{a}$ & $11.54 \mathrm{a}$ & $0.0036 \mathrm{a}$ & $0.0064 \mathrm{a}$ \\
\hline 80 & $62.05 \mathrm{a}$ & $1.67 \mathrm{a}$ & $86 \mathrm{a}$ & $11.02 \mathrm{a}$ & $0.0034 \mathrm{a}$ & $0.0062 \mathrm{a}$ \\
\hline \multicolumn{7}{|c|}{ Spacing between plants } \\
\hline 8 & $51.09 \mathrm{~b}$ & $1.67 \mathrm{a}$ & $87 \mathrm{a}$ & $11.38 \mathrm{a}$ & $0.0033 \mathrm{a}$ & $0.0063 \mathrm{a}$ \\
\hline 12 & $52.19 \mathrm{ab}$ & $1.68 \mathrm{a}$ & $84 \mathrm{a}$ & $1158 \mathrm{a}$ & $0.0034 \mathrm{a}$ & $0.0062 \mathrm{a}$ \\
\hline 16 & $60.62 \mathrm{a}$ & $1.72 \mathrm{a}$ & $85 \mathrm{a}$ & $11.69 \mathrm{a}$ & $0.0035 \mathrm{a}$ & $0.0065 \mathrm{a}$ \\
\hline
\end{tabular}

Panicle weight (PW), 100 seed weight (HSW), germination (G), shoot length (SL), root dry matter (RDM), shoot dry matter (SDM). Mean values followed by the same letter in a column do not differ by the non-parametric Kruskal-Wallis test at $5 \%$ significance.

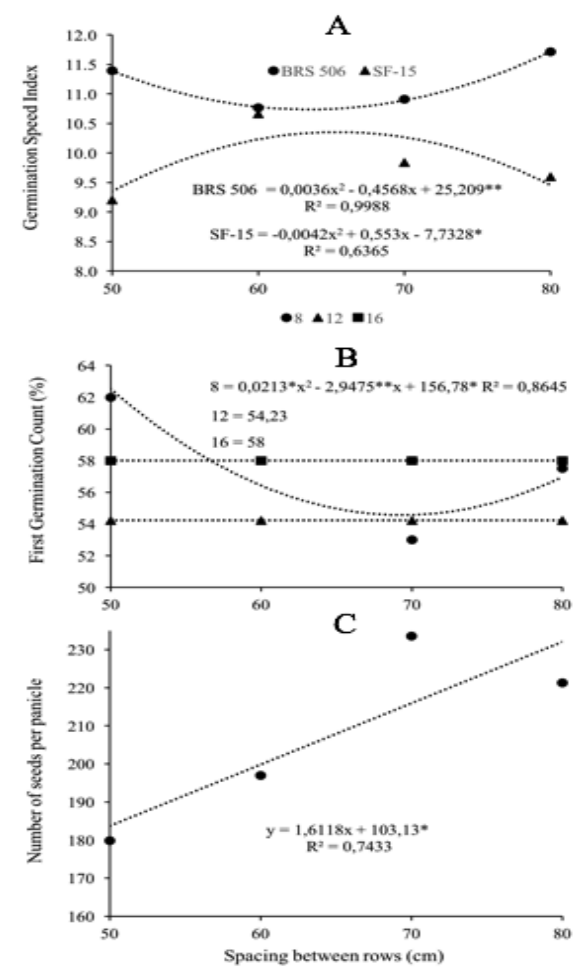

Fig 1. Number of seeds per panicle (A), germination speed index (B) and first percentage of germination in first count at 4 days after sown (C) of sweet sorghum seeds from two cultivars produced in semi-arid region using different spacing between rows. * and $* *$ significant by F-test at $5 \%$ and $1 \%$ probability.

Table 2. Summary of Analysis of Variance for variables with data normalised by the Box-Cox system for cultivar (CV), spacings between rows (SR) and spacings between plants (SP): Seed water content (SWC), number of seeds per panicle (NSP), germination speed index (GSI), first germination count (FC), root length (RL) and accelerated ageing (AA), in sweet sorghum cultivars produced in semi-arid region.

\begin{tabular}{|c|c|c|c|c|c|c|c|}
\hline \multirow{2}{*}{ SV } & \multirow{2}{*}{$\mathrm{DF}$} & SWC $(\%)$ & NSP & GSI $(\%)$ & $\mathrm{FC}$ & RL (cm) & AA $(\%)$ \\
\hline & & \multicolumn{6}{|c|}{ - } \\
\hline Block & 3 & $0.000031^{\mathrm{ns}}$ & $14217.367159^{\mathrm{ns}}$ & $0.141237^{\mathrm{ns}}$ & $50.7083^{\text {ns }}$ & $2.886058^{\mathrm{ns}}$ & $31188305.7^{\mathrm{ns}}$ \\
\hline $\mathrm{CV}$ & 1 & $0.000004^{\text {ns }}$ & $7866.079376^{\mathrm{ns}}$ & $45.0319 * *$ & $1335.042 * *$ & $0.653400^{\mathrm{ns}}$ & $703510157.2^{* *}$ \\
\hline SR & 3 & $0.000153^{\mathrm{ns}}$ & $13981.185170^{*}$ & $0.99757^{\mathrm{ns}}$ & $74.37500^{\mathrm{ns}}$ & $0.445411^{\mathrm{ns}}$ & $5360509.1^{\mathrm{ns}}$ \\
\hline SP & 2 & $0.000067 *$ & $8857.258739^{\mathrm{ns}}$ & $2.460429^{\mathrm{ns}}$ & $673.7916^{*}$ & $3.025426^{\mathrm{ns}}$ & $21938169.4^{\mathrm{ns}}$ \\
\hline $\mathrm{Cv} \times \mathrm{SR}$ & 3 & $0.000679 * *$ & $3570.962615^{\mathrm{ns}}$ & $5.83877^{*}$ & $381.1528^{\mathrm{ns}}$ & $2.290033^{\mathrm{ns}}$ & $35765257.4^{\mathrm{ns}}$ \\
\hline $\mathrm{Cv} \times \mathrm{SP}$ & 2 & $0.000054^{\mathrm{ns}}$ & $4752.875939^{\mathrm{ns}}$ & $0.291017^{\mathrm{ns}}$ & $153.7916^{\mathrm{ns}}$ & $7.064816^{*}$ & 94982129.7* \\
\hline SR $x$ SP & 6 & $0.000099^{\mathrm{ns}}$ & $3395.208587^{\mathrm{ns}}$ & $2.332328^{\mathrm{ns}}$ & $475.7916^{*}$ & $1.596237^{\mathrm{ns}}$ & $82291568.4 * *$ \\
\hline $\mathrm{Cv} \times \mathrm{SR} \times \mathrm{SP}$ & 6 & $0.000183^{* *}$ & $3495.837215^{\mathrm{ns}}$ & $4.058232 *$ & $1018.9027 * *$ & $0.234041^{\mathrm{ns}}$ & $9907657.9^{\mathrm{ns}}$ \\
\hline Error & 69 & 0.000041 & 5329.054109 & 1.679052 & 0.255631 & 1.229103 & 26139936.1 \\
\hline Total & 95 & - & - & - & - & - & - \\
\hline $\mathrm{CV}(\%)$ & - & 0.91 & 35.11 & 12.33 & 15.96 & 7.22 & 30.83 \\
\hline
\end{tabular}

SV: source of variation; DF: degree of freedom; MS: mean square; CV: coefficient of variation; ns, *, ** respectively: not significant, significant at $5 \%$ and at $1 \%$ probability by F-test for the analysis of variance (ANOVA). 
Table 3. Seed water content and germination speed index in two sweet sorghum seeds cultivars produced in the semi-arid region using different spacing between rows.

\begin{tabular}{|c|c|c|c|c|}
\hline Cultivar & $50 \mathrm{~cm}$ & $60 \mathrm{~cm}$ & $70 \mathrm{~cm}$ & $80 \mathrm{~cm}$ \\
\hline \multicolumn{5}{|c|}{ 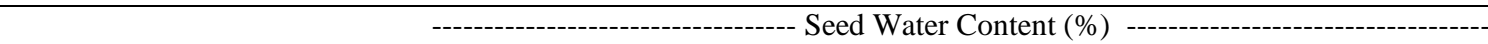 } \\
\hline BRS 506 & $9.57 \mathrm{a}$ & $9.25 \mathrm{a}$ & $8.82 \mathrm{~b}$ & $10.28 \mathrm{a}$ \\
\hline SF-15 & $10.09 \mathrm{a}$ & $9.25 \mathrm{a}$ & $11.63 \mathrm{a}$ & $7.98 \mathrm{~b}$ \\
\hline & & Jerminat & $(\%)--$ & --------- \\
\hline BRS 506 & $11.39 \mathrm{a}$ & $10.76 \mathrm{a}$ & $10.91 \mathrm{a}$ & $11.71 \mathrm{a}$ \\
\hline SF-15 & $9.21 \mathrm{~b}$ & $10.66 \mathrm{a}$ & $9.83 \mathrm{~b}$ & $9.59 \mathrm{~b}$ \\
\hline
\end{tabular}

${ }^{\mathrm{a}, \mathrm{b}}$ Same letters in a column do not differ by Tukey's test at a level of $5 \%$.

Analysis of the breakdown for water content and germination seed index of the cultivars within each spacing between rows.

Table 4. First germination count and root length in two cultivars of sweet sorghum produced in the semi-arid region using different spacing between plants

\begin{tabular}{|c|c|c|c|}
\hline Cultivar & $8 \mathrm{~cm}$ & $12 \mathrm{~cm}$ & $16 \mathrm{~cm}$ \\
\hline & \multicolumn{3}{|c|}{---------- First germination count (\%) -------- } \\
\hline BRS 506 & $69.62 \mathrm{a}$ & $58.37 \mathrm{a}$ & $58.62 \mathrm{a}$ \\
\hline SF-15 & $57.62 \mathrm{~b}$ & $51.25 \mathrm{a}$ & $55.37 \mathrm{a}$ \\
\hline & \multicolumn{3}{|c|}{--------------- Root lenght $(\mathrm{cm})$-------------- } \\
\hline BRS 506 & $16.04 \mathrm{a}$ & $14.75 \mathrm{a}$ & $14.99 \mathrm{a}$ \\
\hline SF-15 & $15.14 \mathrm{~b}$ & $15.25 \mathrm{a}$ & $15.89 \mathrm{a}$ \\
\hline
\end{tabular}

${ }^{\mathrm{a}, \mathrm{b}}$ Same letters in a column do not differ by Tukey's test at a level of $5 \%$.

Analysis of the breakdown for first germination count and root length of the cultivars within each spacing between plants.

Table 5. Percentage of germinated seeds after accelerated ageing evaluation in two cultivars of sweet sorghum produced in semi-arid region using different spacing between plants (SP).

\begin{tabular}{|c|c|c|c|c|}
\hline & $50 \mathrm{~cm}$ & $60 \mathrm{~cm}$ & $70 \mathrm{~cm}$ & $80 \mathrm{~cm}$ \\
\hline Cultivar & \multicolumn{4}{|c|}{-------------- Germination after accelerated ageing $(\%)$--------------- } \\
\hline BRS 506 & $81.57 \mathrm{a}$ & $78.66 \mathrm{a}$ & $80.78 \mathrm{a}$ & $82.78 \mathrm{a}$ \\
\hline SF-15 & $68.74 \mathrm{~b}$ & $75.37 \mathrm{a}$ & $68.92 \mathrm{~b}$ & $69.78 \mathrm{~b}$ \\
\hline SP & \multicolumn{4}{|c|}{---------------- Germination after accelerated ageing (\%) ---------------- } \\
\hline 8 & $72.12 \mathrm{a}$ & $74.45 \mathrm{a}$ & $77.06 \mathrm{a}$ & $79.48 \mathrm{ab}$ \\
\hline 12 & $82.07 \mathrm{a}$ & $78.66 \mathrm{a}$ & $67.94 \mathrm{a}$ & $68.73 \mathrm{~b}$ \\
\hline 16 & $71.79 \mathrm{a}$ & $78.01 \mathrm{a}$ & $79.82 \mathrm{a}$ & $80.99 \mathrm{a}$ \\
\hline
\end{tabular}

${ }^{\mathrm{a}, \mathrm{b}}$ Same letters in a column do not differ by Tukey's test at a level of $5 \%$.

Analysis of the breakdown for accelerated ageing of the cultivars within each spacing between rows and analysis of the breakdown for accelerated ageing of the cultivars for spacing between plants within each spacing between rows.

Table 6. Meteorological parameters for the period from March to July 2015 in Brazilian semi-arid region (Pentecoste, Ceará, Brazil).

\begin{tabular}{lccccc}
\hline \multirow{2}{*}{ Period } & \multicolumn{2}{c}{ Temperature $\left({ }^{\circ} \mathrm{C}\right)$} & \multicolumn{2}{c}{ Relative Humidity $(\%)$} & Rainfall (mm) \\
\cline { 2 - 5 } & $09: 00$ & $15: 00$ & $09: 00$ & $15: 00$ & 246.6 \\
March $(07-31)$ & 28.4 & 29.6 & 86.1 & 82.3 & 266.2 \\
April & 27.8 & 28.7 & 88.6 & 60.4 & 31.6 \\
May & 30.4 & 33.1 & 73.2 & 51.6 & 40 \\
June & 30.4 & 33.9 & 65.7 & 56.5 & 56.2 \\
July & 28.5 & 32.8 & 67.7 & & 640.6 \\
\hline Total & \multicolumn{7}{c}{} \\
\hline
\end{tabular}

Source: Ceará State's Foundation for Meteorology and Water Resources - FUNCEME, Brazil (www.funceme.br).

Table 7. Physical and chemical conditions of the soil at depths of 0-20 and 20-40 cm from the experimental area of Vale-do-Curu Farm in Brazilian semi-arid region (Pentecoste, Ceará, Brazil).

\begin{tabular}{|c|c|c|c|c|c|c|c|c|}
\hline Depth $(\mathrm{cm})$ & $\mathrm{Ca}^{2+}$ & $\mathrm{Mg}^{2+}$ & $\mathrm{Na}^{+}$ & $\mathrm{K}^{+}$ & $\mathrm{H}^{+}+\mathrm{Al}^{3+}$ & $\mathrm{Al}^{3+}$ & $\mathrm{S}$ & $\mathrm{T}$ \\
\hline $0-20$ & 5.80 & 1.20 & 0.33 & 0.49 & 1.49 & 0.15 & 7.8 & 9.3 \\
\hline \multirow[t]{2}{*}{$20-40$} & 5.40 & 1.60 & 0.37 & 0.35 & 1.16 & 0.10 & 7.7 & 8.9 \\
\hline & $\begin{array}{l}\mathrm{V} \\
---\% \text {--- }\end{array}$ & $\mathrm{M}$ & $\begin{array}{l}\mathrm{C} \\
-\end{array}$ & $\mathrm{N}$ & $\mathrm{OM}$ & Assimilated P & $\mathrm{C} / \mathrm{N}$ & PST \\
\hline $0-20$ & 84 & 2 & 6.66 & 0.73 & 11.48 & 0.086 & 9 & 4 \\
\hline \multirow[t]{2}{*}{$20-40$} & 87 & 1 & 3.72 & 0.34 & 6.41 & 0.053 & 11 & 4 \\
\hline & $\begin{array}{l}\text { BD } \\
\text { g.cm }{ }^{-3}\end{array}$ & $\begin{array}{l}\mathrm{pH} \\
\mathrm{H}_{2} \mathrm{O}\end{array}$ & $\begin{array}{l}\text { EC } \\
\text { dS.m }{ }^{-1}\end{array}$ & $\begin{array}{l}\text { Course } \\
\text { Sand }\end{array}$ & Fine Sand & $\begin{array}{l}\text { Silt } \\
\mathrm{kg}^{-1}-\end{array}$ & Clay & Nat. Clay \\
\hline $0-20$ & 1.46 & 6.7 & 0.85 & 68 & 593 & 249 & 90 & 61 \\
\hline $20-40$ & 1.55 & 7.0 & 0.66 & 50 & 571 & 271 & 108 & 92 \\
\hline
\end{tabular}

Source: Soil/Water Laboratory, Department of Soil Science - UFC; Ceará State's Foundation for Meteorology and Water Resources - FUNCEME. 
Probably because the storage conditions were similar, there was no significant variation between cultivars. The reduction in water content seen for the SF-15 cultivar at the spacing of $80 \mathrm{~cm}$ can be attributed to the fact that it spent more time in the field under high temperatures and at a larger spacing, which may have resulted in a greater loss of water. According to Ferreira et al. (2013), water content directly affects seed quality: the greater the water content of the seed when harvested, the greater the probability of mechanical damage, making it necessary to give great attention to this stage of production.

\section{Regression analysis}

It can be seen in Figure 1A that the number of seeds per panicle displayed linear behaviour for the regression model. It was found that as the spacing between rows increased, there was also an increase in the number of seeds per panicle. The lowest value found for the number of seeds was at the spacing of $50 \mathrm{~cm}$ between rows, with 184 seeds; the highest value was at $80 \mathrm{~cm}$, with 232 seeds per panicle. It can have been seen that a larger spacing between rows therefore favours greater seed production. These results agree with those reported by Santos et al. (2002), working with two cultivars of upland rice at different spacings, where it was found that at the largest inter-row spacing, a greater number of grains were obtained per panicle.

It is therefore likely that greater efficiency in the capture of photosynthetically active radiation was obtained at the largest plant spacing, contributing to better development and therefore to the process of seed formation. Among the cultivars under study, the potential for seed production would have been much greater if there had been no predation by birds during the field experiment.

A higher germination speed index is seen for the BRS 506 cultivar at most of the spacings adopted (Table 3). The SF-15 genotype had a lower germination speed index at the spacing of $50 \mathrm{~cm}$ between rows, which is the lowest value seen in the data, with 9.21 seedlings germinated per day.

Figure 1B shows the behaviour of the two cultivars in relation to the germination speed index (GSI) for row spacing. The BRS 506 cultivar had a lower index at a spacing of $63.44 \mathrm{~cm}$, with the value of 10.72 calculated by regression (Fig 1B), whereas the highest value was found at $80 \mathrm{~cm}$ with a GSI of 11.71. The SF-15 cultivar achieved lower results for GSI compared to the values for BRS 506. The lowest value found was at the spacing of $50 \mathrm{~cm}$ with a GSI of 9.42, while the highest value was at $65.83 \mathrm{~cm}$, with a GSI of 10.47 (Fig $1 \mathrm{~A}$ and Table 3). The germination speed index is important in the study of seeds, being a part of the tests to evaluate vigour which are aimed at determining the physiological potential of a seed lot and detecting significant differences, besides providing additional information necessary to evaluate seed production (Marcos Filho, 2005).

From the data for first germination count (FC), there was only a difference at the spacing of $8 \mathrm{~cm}$ between plants in relation to the SF-15 genotype, which had a count below that of BRS 506, with a value of $57.6 \%$ (Table 4). This result can be attributed to the cultivar not having developed well at the smaller spacing due to the lower availability of resources; the plants were more densely packed, and probably entered into competition for such environmental factors as water, light and nutrients. The first count is also a part of the tests to evaluate vigour, required for seeds; it reflects the expression of a set of characteristics that determine the potential for rapid and uniform seedling emergence (Marcos Filho, 2005).
There was no significant difference for the other spacings between plants.

According to Figure 1C, the plant spacing of $8 \mathrm{~cm}$ had a minimum value of $54.8 \%$ for first count at a row spacing of $69.19 \mathrm{~cm}$, whereas the maximum value obtained for first count was $62.6 \%$ at the spacing of $50 \mathrm{~cm}$ between rows. The other spacings between plants did not fit any of the proposed models. Values for the two cultivars under evaluation differed from values found by Vazquez et al., (2011), who worked with different batches of the BRS 610 cultivar and obtained far higher values for first count that ranged from $87 \%$ to $100 \%$. This result can be attributed to the authors having worked with a single F1 generation hybrid while the present work was developed using F2 generation seeds.

The values for root length can be found in Table 4. Note that only the SF-15 cultivar showed a significant difference at the spacing of $6 \mathrm{~cm}$ between plants. In places with irregular rainfall distribution, as in the semi-arid region, root length is one of the characteristics that help the plant to maintain itself in the environment; more-developed roots afford the plant a larger supply of water, and the deeper soil layers help plant survival under drought conditions.

\section{Seed vigour}

In Table 5 can be found the values for the accelerated ageing test, it should be noted that after the test between the two sweet sorghum genotypes the results for normal seedlings ranged from $68.74 \%$ to $82.78 \%$. This differed from results obtained by Oliveira et al. (2014), where it was not possible to see any effect from sowing density or row spacing on the production of turnip seeds, noting that after the accelerated ageing test the percentage of normal seedlings varied from $87 \%$ to $94 \%$. Miranda et al., (2001), working with different batches of sorghum seed from the Zeneca 822 cultivar at the same exposure time and temperature adopted in the experiment (96 hours at $41^{\circ} \mathrm{C}$ ), found variations in germination from $83 \%$ to $92 \%$ between batches.

The results of the accelerated ageing test present values with significant differences only for the spacing of $80 \mathrm{~cm}$ between rows, with a value of $68.7 \%$ (Table 5). According to Miranda et al. (2001), the accelerated ageing test is complementary to the germination test, as it is in the latter test that the seeds are subjected to similar factors to those found in the field, considered adverse environmental factors which consider the high levels of relative humidity and temperature that contribute to a higher rate of seed deterioration.

Note the behaviour of both cultivars for the accelerated ageing test in relation to the breakdown of plant spacing within each level of row spacing (Table 5). At the spacing of $16 \mathrm{~cm}$ between plants, a value of $71.8 \%$ germination is seen for seeds obtained at the spacing of $50 \mathrm{~cm}$ between rows, and $81 \%$ germination at the spacing of $80 \mathrm{~cm}$ between rows.

\section{Materials and Methods}

\section{Location and edaphoclimatic conditions}

The experiment was carried out from March to July 2015 under rainfed conditions, at the Vale do Curu Experimental Farm of the Federal University of Ceará - UFC, in Pentecoste, CE, at UTM coordinates 462620 E, 9577349 S, and an altitude of $48 \mathrm{~m}$, in a Luvisol of a sandy loam texture. The local climate according to the Köppen classification (Alvares et al., 2014), is of type BSw'h, the region belonging 
to the semi-arid group of climates. Meteorological data for the period of the experiment are presented in Table 1 .

\section{Plant materials}

The cultivars used were BRS 506, acquired from the Corn and Sorghum unit of the Brazilian Company for Agricultural Research - EMBRAPA in the city of Sete Lagoas in Minas Gerais, and SF-15, from the Agronomic Institute of Pernambuco - IPA. For the two cultivars under study (BRS 506 and SF-15), spacings between rows of 50, 60, 70 and 80 $\mathrm{cm}$, and between plants of 8,12 and $16 \mathrm{~cm}$, were analysed, resulting in different plant populations per hectare.

\section{Experimental design and conduction}

Soil preparation was by ploughing followed by harrowing. The experiment was conducted in a randomised block design with four replications, in a $2 \times 4 \times 3$ factorial scheme, comprising two cultivars, four spacings between rows and three spacings between plants, for a total area of 1,248 $\mathrm{m}^{2}$, with four blocks of $312 \mathrm{~m}^{2}$ and lots that varied from 10 to 16 $\mathrm{m}^{2}$ according to the treatment. Each lot consisted of four rows of five metres, the two central rows making up the usable area of the lot.

According to soil the analysis (Table 2) of the experimental area and the recommendations of Durães et al. (2012), base fertilisation was carried out with 30,50 and $45 \mathrm{~kg} \mathrm{ha}^{-1} \mathrm{~N}$, $\mathrm{P}_{2} \mathrm{O}_{5}$ and $\mathrm{K}_{2} \mathrm{O}$ respectively; the sources for each nutrient were the mineral fertilisers urea, single superphosphate and potassium chloride. At 20 days after sowing, cover fertilisation was carried out using 140 and $45 \mathrm{~kg} \mathrm{ha}^{-1} \mathrm{~N}$ and $\mathrm{K}_{2} \mathrm{O}$ respectively.

\section{Traits measured}

Three panicles were collected from each usable area at 110 days after sowing (DAS) for the BRS 506 cultivar, and at 130 DAS for the SF-15 cultivar. The panicles were taken to the Seed Analysis Laboratory (UFC), where the panicles were weighed, and the seeds extracted and counted. The following analyses were then performed: number of seeds per panicle; 100 seed weight (Santos et al., 2008); water content, using four replications of 30 seeds and employing the oven method $\left(105 \pm 2{ }^{\circ} \mathrm{C}\right.$ for 24 hours); germination test, determined as a percentage of normal seedlings in four replications of 50 seeds per treatment (Brasil, 2009); first germination count, at four days after setting up the germination test; germination speed index (Maguire, 1962); accelerated ageing test, using 50 seeds for each of the four replications of each treatment (Vazquez et al., 2011; Oliveira et al., 2012); and seedling evaluation at ten days after setting up the germination test. For this last evaluation, 20 seedlings were removed at random to measure shoot and root length, and determine dry matter weight (Marcos Filho, 1994; Oliveira et al., 2011).

\section{Statistical analysis}

The data were subjected to tests of normality and homogeneity of variance, and when these assumptions were met, an analysis of variance (ANOVA) was carried out, followed by Tukey's test (5\%) for the variety and spacing between plants, and polynomial regression for the spacing between rows. When the data did not meet at least one of the assumptions of ANOVA, they were submitted to the nonparametric Kruscal-Wallis test (5\%). The variables WC (\%),
GSI, FC and AA were analysed using data transformed by the Box-Cox system.

The statistical analyses were performed with the aid of the following software: Action 2.7 (ESTATCAMP, 2014) for the Box-Cox transformation and Bartlett test (test of variance); Assistat 7.7 beta (Silva and Azevedo, 2016) for the normality and Kruscal-Wallis tests; and Sisvar 5.3 Build 77 (Ferreira, 2011) for the ANOVA using Tukey's test or regression.

\section{Conclusions}

Sweet sorghum cv. BRS 506 is well adapted to grow in semiarid region. Besides that, we observed that plant arrangement influences the physiological quality of sweet sorghum seeds. Therefore, to produce sweet sorghum seeds of this cultivar we recommend the spacing of $16 \mathrm{~cm}$ between plants and 80 $\mathrm{cm}$ between rows, at a density of 78,125 plants per hectare.

\section{Acknowledgments}

The authors thank the Coordination for the Improvement of Higher Education Personnel (Coordenação de Aperfeiçoamento de Pessoal de Nivel Superior - CAPES, Brazil) for its financial support.

\section{References}

Alvares CA, Stape JL, Sentelhas PC, Gonçalves JL, Sparovek G (2014) Köppen's climate classification map for Brazil. Meteorologische Zeitschrift, 22(6): 711-728.

Alvarez CGD, Pinho RG, Von-Borges ID (2006) Avaliação de características agronômicas e de produção de forragem e grãos de milho em diferentes densidades de semeadura e espaçamentos entre linhas. Ciência e Agrotecnologia, 30(3): 402-408.

Brasil (2009) Ministério da Agricultura, Pecuária e Abastecimento. Regras para análise de sementes. Ministério da Agricultura, Pecuária e Abastecimento. Secretaria de Defesa Agropecuária. Brasília: MAPA/ACS, p 395.

Carvalho NM, Nakagawa J (2012) Sementes: Ciência, tecnologia e produção. 5 edição ed. Campinas: FUNEP.

Cunha SP, Severo-Filho WA (2010) Avanços tecnológicos na obtenção de etanol a partir de sorgo sacarino (Sorghum bicolor (L.) Moench). Tecno-Lógica, 14(2): 69-75.

Durães FOM, May A, Parrella RA (2012) Sistema Agroindustrial do Sorgo Sacarino no Brasil e a Participação Público- Privada: Oportunidades, Perspectivas e Desafios. Documentos / Embrapa Milho e Sorgo, p. 76.

ESTATCAMP. Software Action, (2014) Available in <http://www.estatcamp/empresa/software-action>

Evangelista JRE, Oliveira JA, Guimarães RM, Botelho FJE, Resende PM, Mondo VHV (2015) Potencial fisiológico de sementes de soja durante a maturação. Informativo ABRATES, 25: 39-42.

Fernandes PG, May A, Coelho FC, Abreu MC, Bertolino KM (2014) Influência do espaçamento e da população de plantas de sorgo sacarino em diferentes épocas semeadura. Ciência Rural, 44(6): 975-981.

Ferreira DF (2011) Sisvar: a computer statistical analysis system. Ciência e Agrotecnologia, 6: 1039-1042.

Ferreira VF, Oliveira JA, Ferreira TF, Reis LV, Andrade V, Costa Neto C (2013) Quality of maize seeds harvested and husked at high moisture levels. Journal of Seed Science, 35(3): 276-283. 
Fischer-Filho JA, Gomes GGC, Bolonhezi AC, Oliveira JAV, Santos BTRR (2014) Sacarino characteristics of growth of hybrid sorghum. Ciência \& Tecnologia: FatecJB, Jaboticabal, 6: 11-15.

Fontes MM, Silva BA, Dantas JP, Silveira DC, Cavalcanti MT (2011) Caracterização físico-químico do melado de sorgo physical-chemical sorghum molasses cane [Sorghum biolor ( L ) Moench]. Revista Verde de Agroecologia e desenvolvimento sustentável, 6(1): 216-219.

Maguire JD (1962) Speed of germination-aid in selection and evaluation for seedling emergence and vigor. Crop Science, 2: 176-177.

Marcos Filho J (1994) Utilização de testes de vigor em programas de controle de qualidade de sementes. Informativo ABRATES, Londrina, 4: 33-35.

Marcos Filho J (2005) Fisiologia de sementes de plantas cultivadas. Piracicaba, FEALQ. p. 495.

Martins ABN, Costa CJ, Quineper RR, Monteiro MA, Véra JG, Medeiros L (2014) Qualidade fisiológica de sementes de sorgo sacarino em função do espaçamento e desnidade de plantas. $12^{\mathrm{a}}$ Jornada de Pós-Graduação e Pesquisa p.1982-2960.

Miranda DM, Novembre ADDLC, Chamma HMCP (2001) Avaliação do potencial fisiológico de sementes de sorgo pelo teste de envelhecimento acelerado. Revista Brasileira de Sementes, 23: 226-231.

Oliveira AB, Gomes-Filho E, Enéas-Filho J, Prisco JT, Alencar NLM (2012) Seed priming effects on growth, lipid peroxidation and activity of ROS scavenging enzymes in $\mathrm{NaCl}$-stressed sorghum seedlings from aged seeds. Journal of Plant Interactions, 7:151-159.

Oliveira AB, Alencar NLM, Prisco JT, Gomes-Filho E (2011) Accumulation of organic and inorganic solutes in $\mathrm{NaCl}$-stressed sorghum seedlings from aged and primed seeds. Scientia Agricola 68:632-637.

Oliveira SSCD, Martins CC, Cruz SJS and Silva CJD (2014) Seleção de progênies de nabo-forrageiro para germinação sob altas temperaturas. Ciência Rural, pp.217-222.

Pinto ORO, Azevedo BM, Marinho AB, Fernandes CNV, Viana TVA, Braga EB (2011) Adubação nitrogenada na cultura do sorgo granífero pelo método. Agropecuária Técnica, 32(1): 132-140.
Queiroz TR, Queiroz TR, Beraldo MA, Ernesto RC, Yoshimura BK (2013) Análise da viabilidade econômica e as potencialidades de produção de biocombustível a partir do sorgo sacarino (Sorghum bicolor (L.) Moench). Disponível em: <http://www.xxivenangrad.enangrad. org.br/anais2013/_resources/artigos/gds/07.pdf $>$

Ribeiro Filho NM, Florêncio IM, Rocha AS, Dantas JP, Florentino ER, Silva HFL (2008) Aproveitamento do caldo do sorgo sacarino para produção de aguardente. Revista Brasileira de Produtos Agroindustriais, 10(1): 9-16.

Santos HC, Viana JS, Goncalves EP, Bruno RLA, Fraga VS (2008) Physiological Quality of Sorghum Seeds in Response To Copper. Caatinga (Mossoró,Brasil), 21: 6470.

Santos PG, Castro AP, Soares AA, Cornélio VMO (2002) Effect of spacing and seed density on yield of Sprinklerirrigated upland rice. Ciência e Agrotecnologia, 26: 480487.

Silva FAZ, Azevedo CAV (2016) Comparison of means of agricultural experimentation data through different tests using the software Assistat. Afr. J. Agric. Res. 11(37): 3527-3531.

Souza CC, Dantas JP, Silva SM, Souza VC, Almeida FA, Silva LE (2005) Produtividade do Sorgo granífero cv. sacarino e qualidade de produtos formulados isoladamente ou combinados ao caldo de cana-de-açúcar. Ciência e Tecnologia de Alimentos, 25(3): 512-517.

Toledo MZ, Cavariani C, Nakagawa J, Alves E, Mateus GP, Crusciol CAC (2007) Qualidade fisiológica de sementes de sorgo-de-guiné em função da adubação nitrogenada em cobertura. Revista Brasileira de Milho e Sorgo, 6(2): 234246

Ullmann R, Resende O, Chaves, TH, Oliveira, DEC, Costa, LM (2015) Qualidade fisiológica das sementes de sorgo sacarino submetidas à secagem em diferentes condições de ar. Revista Brasileira de Engenharia Agrícola e Ambiental, 19: 64-69.

Vazquez GH, Bertolin DC, Spegiorin CN (2011) Testes de envelhecimento acelerado e de condutividade elétrica para avaliar a qualidade fisiológica de sementes de sorgo (Sorghum bicolor (L .) Moench). Revista Brasileira de Biociências, 9: 18-24. 